\title{
NUMBERED-HEAD TOGETHER IN TEACHING READING NARRATIVE
}

\author{
Anisa Ramadhanty ${ }^{1}$, Yayan Ruyani ${ }^{2}$, Trisnendri Syahrizal ${ }^{3}$ \\ ${ }^{1}$ IKIP Siliwangi \\ ${ }^{2}$ IKIP Siliwangi \\ ${ }^{3}$ IKIP Siliwangi \\ ${ }^{1}$ anisaramadhanty97@gmail.com, ${ }^{2}$ yayanruyani22@ gmail.com, ${ }^{3}$ trisnendri@ikipsiliwangi.ac.id
}

\begin{abstract}
Reading comprehension is needed by students in order to have a good reading skill. In this journal, the researchers are trying to examine the implementation of NHT technique in improving students' reading comprehension of narrative text. Quantitative used as the research method with pre-experimental research design. There are three stages in conducting pre-experimental design. First, students are given pre-test to measure their knowledge. Second, students are given the treatment and last, students are given posttest after using NHT technique. In conducting the data, the researchers spend seven times consisted of pretest, posttest, and five times treatments. As the result, the mean score of pre-test is 43.58. After implementing NHT technique in every meeting, reading comprehension of students had been getting better, it can be seen in average of the mean score of post-test became 62.45. It can be concluded that NHT technique can improve students' reading comprehension.
\end{abstract}

Keywords: Numbered-head together, Students' reading comprehension

\section{INTRODUCTION}

In Indonesia, English language considered as Foreign Language. By studying and learning English language, students can increase their ability and their experience. It is supported by Lisdawati \& Syahrizal (2012) stated "learning is a process faced by students to enrich their knowledge and expertise". In fact, Indonesian students might have some difficulties in studying English language. Moreover, students should learn and master four skills in English language. One of the skills in English is reading skill.

Reading is an activity informed by the apprehension of images, shapes, patterns, and rhythms, which come to be recognized through repeated encounters and remembered forms; the meanings that are made in reading are in excess of the meanings that arise from the interpretation of written language (Lorange, 2014: 30) as cited in Parmawati (2018). Reading is an activity of interpreting the text from journal, book, novel and article to get the meaning of it. In addition Harmer (2007) stated that reading is helpful for acquiring the language. It produced that students less or more understanding of what they read. In line with Apsari \& Yana (2015) state "reading is not only important in developing language intuition and determining academic success but also in completing certain task". It can be concluded that reading is one of the important factors to acquire the language. It is because through reading activity students can learn about vocabularies, grammar, spelling and punctuation. Students should have a good reading skill in order to finish their task. One of the ways to do it is through comprehend the text well. As stated by Apsari (2014) that acquiring reading skill requires one to be able to comprehend the text itself. 
The way of understanding and comprehending the text to get the required information is called reading comprehension. It is supported by Sinambela, Manik, \& Pangaribuan (2015) that reading comprehension means understanding what has been read and it involves understanding the vocabulary seeing the connection among concepts and words, organizing idea, recognizing authors' purpose, making evaluating and judgement. Unfortunately, there will always be some problems related to teaching reading comprehension. Students might get difficulties in understanding the text, they have lack of vocabulary, they have low motivation in reading or they don't like English subject. Moreover, there are varieties of reading texts such as report, procedure, recount, descriptive and narrative and students should understand it. In this research, it only focuses on narrative text as one of text that should be learned by students in vocational high school. Therefore, to avoid students' difficulties that appeared in reading comprehension, the teacher should select the appropriate technique. The teacher can apply numbered-head together technique in the teaching-learning process as the alternative solution.

By applying Numbered-Head Together, students feel more pleasant and fun in studying English specifically in reading narrative text. Moreover, they feel confident, enjoy and they can teach each other in their group with their own knowledge. It is supported by Nurdiana (2016) that NHT technique is used to develop students' understanding about the material, check their comprehending and understanding about the subject and also to develop students' group work.

The researchers hope that by applying numbered-head together technique, it can encourage students to comprehend in reading narrative text and also it can make students to interest in English subject. It is supported by Febriyanti et al., (2015) numbered-head together technique can improve students' achievement, deepen students' understanding, make students happy in teaching-learning process, develop students' positive attitude, develop students' leadership, develop students' curiosity and improve students' self-confidence. Based on the ideas above, the researchers conducted the research entitled "Numbered-Head Together In Teaching Reading Narrative".

\section{METHOD}

This research held in January-March 2019 at the tenth-grade students in SMKN 2 Cimahi in the academic year 2018/2019. The participant in this journal is one class consists of thirty one students. According to Creswell (2002) quantitative, qualitative and mixed method are the varieties of research method. In this journal, quantitative used as the research method with preexperimental research design. It was considered that quantitative method is appropriate to analyze the implementation of numbered-head together technique to improve students' reading comprehension and also it was because there were pretest, treatments and posttest given toward students. In addition, Wiersma (1995: 14) in Imro'atul (2011) stated "Quantitative research relies heavily on statistical result represented with number". In conclusion, quantitative cannot be separated from statistical data.

This research also uses pre-experimental design with One-Group Pretest-Posttest design. It means a single group was measured not only before given a treatment but also after it. There are three steps in conducting pre-experimental design in this research: First, the researchers gave pretest to the students before using NHT technique. It was because the researchers preferred to know students' knowledge in reading comprehension of narrative text. Second, the researchers performed several treatments section to the students by applying NHT technique. The researchers got the material from internet for the treatment and it was conducted five times. Last, the researchers distributed posttest after applying treatment toward students. As the 
instruments of the research, pretest and posttest contain of thirty multiple choice items about narrative text. The students answered the test in ninety minutes. The goal of this posttest was to recognize reading comprehension of students in narrative text after using NHT technique. After of all those steps, the researchers used SPSS Statistics 23 as a tool for analyzing and calculating the data of both pretest and posttest. The researchers also find out students' N-Gain score by using this formula:

$$
\text { Normalized Gain }(g)=\frac{\text { Posttest score }- \text { Pretest Score }}{\text { Maximum Score }- \text { Pretest Score }}
$$

Then, the researchers categorized students' N-Gain score based on Heke (1999) in Sundayana, (2016):

Table 1. Interpretation of N-Gain

\begin{tabular}{c|c}
\hline Normalized Gain Score & Interpretation \\
\hline$-1.00<\mathrm{g}<0.00$ & Decrease \\
\hline $\mathrm{g}=0.00$ & Stable \\
\hline $0.00<\mathrm{g}<0.30$ & Low \\
\hline $0.30<\mathrm{g}<0.70$ & Average \\
\hline $0.70<\mathrm{g}<1.00$ & High \\
\hline
\end{tabular}

\section{RESULTS AND DISCUSSION}

\section{Results}

The researchers collected the data from pretest and posttest. The detail of students' scores as follows:

Table 2. The Score of Pretest, Posttest and N-Gain

\begin{tabular}{|c|c|c|c|c|c|}
\hline \multirow{2}{*}{ No } & \multirow{2}{*}{ Students } & \multicolumn{3}{|c|}{ Scores } & \multirow{2}{*}{$\begin{array}{c}\text { Interpretation } \\
\text { of N-Gain }\end{array}$} \\
\hline & & Pretest & Posttest & N-Gain & \\
\hline 1 & Student 1 & 37 & 47 & 0.16 & Low \\
\hline 2 & Student 2 & 50 & 73 & 0.46 & Average \\
\hline 3 & Student 3 & 53 & 73 & 0.43 & Average \\
\hline 4 & Student 4 & 60 & 67 & 0.18 & Low \\
\hline 5 & Student 5 & 67 & 77 & 0.30 & Low \\
\hline 6 & Student 6 & 23 & 63 & 0.52 & Average \\
\hline 7 & Student 7 & 30 & 47 & 0.24 & Low \\
\hline 8 & Student 8 & 20 & 37 & 0.21 & Low \\
\hline 9 & Student 9 & 37 & 87 & 0.79 & High \\
\hline 10 & Student 10 & 53 & 70 & 0.36 & Average \\
\hline 11 & Student 11 & 60 & 77 & 0.43 & Average \\
\hline 12 & Student 12 & 23 & 47 & 0.31 & Average \\
\hline 13 & Student 13 & 37 & 53 & 0.25 & Low \\
\hline 14 & Student 14 & 33 & 70 & 0.55 & Average \\
\hline 15 & Student 15 & 13 & 47 & 0.39 & Average \\
\hline 16 & Student 16 & 53 & 60 & 0.15 & Low \\
\hline 17 & Student 17 & 37 & 43 & 0.10 & Low \\
\hline
\end{tabular}




\begin{tabular}{lllllc}
\hline 18 & Student 18 & 37 & 73 & 0.57 & Average \\
\hline 19 & Student 19 & 40 & 53 & 0.22 & Low \\
\hline 20 & Student 20 & 57 & 73 & 0.37 & Average \\
\hline 21 & Student 21 & 40 & 50 & 0.17 & Low \\
\hline 22 & Student 22 & 37 & 43 & 0.10 & Low \\
\hline 23 & Student 23 & 63 & 80 & 0.46 & Average \\
\hline 24 & Student 24 & 37 & 63 & 0.41 & Average \\
\hline 25 & Student 25 & 27 & 47 & 0.27 & Low \\
\hline 26 & Student 26 & 37 & 50 & 0.21 & Low \\
\hline 27 & Student 27 & 40 & 53 & 0.22 & Low \\
\hline 28 & Student 28 & 53 & 70 & 0.36 & Average \\
\hline 29 & Student 29 & 47 & 70 & 0.43 & Average \\
\hline 30 & Student 30 & 70 & 80 & 0.33 & Average \\
\hline 31 & Student 31 & 80 & 93 & 0.65 & Average \\
\hline
\end{tabular}

By using SPSS 23, the researchers analyzed the data based on the result of pretest and posttest score.

Table 3. Result of Normality Test

Tests of Normality

\begin{tabular}{|l|r|r|r|r|r|r|}
\hline \multirow{2}{*}{} & \multicolumn{4}{|c|}{ Kolmogorov-Smirnov ${ }^{\mathrm{a}}$} & \multicolumn{3}{c|}{ Shapiro-Wilk } \\
\cline { 2 - 7 } & Statistic & \multicolumn{1}{c|}{ Df } & \multicolumn{1}{c|}{ Sig. } & Statistic & \multicolumn{1}{c|}{ df } & \multicolumn{1}{c|}{ Sig. } \\
\hline Pretes & .171 & 31 & .021 & .971 & 31 & .536 \\
Postes & .160 & 31 & .043 & .948 & 31 & .137 \\
\hline
\end{tabular}

Criteria $\quad:$ If $\mathrm{Sig} \geq 0.05$ (The data was a normal distribution.)

Because the data are less than 33, the results of significance are based on Kolmogorov-Smirnov.

Pretes $\quad$ : Sig $0.021<0.05$

Posttest $\quad$ : Sig $0.043<0.05$

It means that the distribution of the data was not normal. Then, the researchers held to Nonparametric test.

Table 4. Results of Non-parametric Test

Test Statistics ${ }^{\mathrm{a}}$

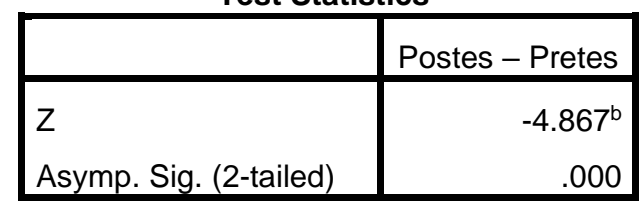

Criteria $\quad:$ If $\mathrm{Sig} \geq 0.05$ (The null hypothesis is accepted)

If Sig < 0.05 (The null hypothesis is rejected) 
The result of Sig. $0.000<0.05$ means that the alternative hypothesis was accepted while the null hypothesis was rejected. Besides that, the researchers used descriptive statistic on SPSS 23 to see the mean and standard deviation.

Table 5. Result of Descriptive Statistics

\begin{tabular}{|l|r|r|r|r|r|}
\hline & $\mathrm{N}$ & Minimum & Maximum & \multicolumn{1}{c|}{ Mean } & Std. Deviation \\
\hline Pretes & 31 & 13 & 80 & 43.58 & 15.675 \\
Postes & 31 & 37 & 93 & 62.45 & 14.665 \\
Valid N (listwise) & 31 & & & & \\
\hline
\end{tabular}

Based on the table above, it shows the improvement statistic of data pretest and posttest, mean of pretest is 43.58 and the mean of posttest is 62.45 and standard deviation has decreased it means the data is representative.

\section{Discussion}

The finding research showed that NHT technique can improve students' reading comprehension. The researchers conducted pretest on $24^{\text {th }}$ January 2019. Based on the Table 2, in the column of Pretest, most of students cannot answer the test well. If they can answer half of questions correctly then they will get 50 score. There are 19 students who cannot answer correctly of the half-question of the test and only 12 students who can pass it. It indicated that students' knowledge in reading narrative text is still low. There are some reasons related to the score of pretest such as they were shocked to do the test, they forgot about narrative text and they felt lazy to read a long text. Meanwhile, posttest conducted on $21^{\text {st }}$ March 2019. In the column of Postest, there is an improvement of the score from previous test to the newest one. Most of students can answer the test correctly. There are 22 students who can get the score are greater than or equal to 50 score. It is because the researchers have applied NHT technique in teaching reading narrative toward students. Besides the result of pretest and posttest, the researchers also used N-Gain formula in order to know students' score in N-Gain and its interpretation. In the column of Interpretation of N-Gain on the Table 2, there are 14 students who categorized low, 1 student who have high interpretation in $\mathrm{N}$-gain score and 16 students are in average level.

As the comparison, students felt more confident and enjoyed to do the test after using NHT. Before using NHT, most students forgot about narrative text although they have learned it in junior high school. They also knew the tips and trick while they were doing the test. It is because the researchers conducted five times treatments. First meeting after giving pretest, students learned about the whole material of narrative text. Second, they learned about generic structure. Third, they learned about language features. Forth, they learned simple past tense and the last treatment they reviewed all about the material that they have learned. In the process of applying numbered-head together, the researchers always gave students the exercises in order to make students comprehend the material.

Based on Table 3, the result of normality test indicates that the data is not normally distributed. It is because the result of pretest and posttest do not fulfill the criteria of normality test. It viewed from the significance score from pretest and posttest. The scores are 0.021 for pretest and 0.043 for posttest. In the other words, the scores are lower than 0.05 . So, the researchers held to NonParametric Test. The result of non-parametric test can be seen on Table 4. It shows that Asymp. 
Sig. (2-tailed) is less than 0.05. It means that the implementation of NHT technique was given a good response from students in their teaching-learning process of reading comprehension. It is also supported by the students' mean score of pretest was 43.58. After implementing NHT technique, the mean scores of posttest became 62.45 .

\section{CONCLUSION}

The aim of this journal is to examine whether the implementation or the use of NHT technique can improve students' reading comprehension or not, with using quantitative method and preexperimental research design. The data was not a normal distribution. Based on the result, the increasing of mean score of pretest 43.58 and the mean of posttest 62.45 indicated that there was an improvement of students' reading comprehension. The result Asymp. Sig. $0.000<0.05$ so it rejects $\mathrm{HO}$ and accepts $\mathrm{H} 1$. It means that score was improve using NHT technique at the tenth-grade students of SMKN 2 Cimahi. In conclusion, NHT technique can improve students' reading comprehension.

\section{ACKNOWLEDGMENTS}

We thank the family, parents, friends and lecturers who have given us support both materially and morally, so the researchers can complete and publish our article.

\section{REFERENCES}

Apsari, Y. (2014). The Use Of Authentic Materials in Teaching Reading Comprehension. ELTIN JOURNAL, Journal of English Language Teaching in Indonesia, 2(2).

Apsari, Y., \& Yana, Y. (2015). Teachers'techniques And Problems In Teaching Reading. P2m Stkip Siliwangi, 2(2), 217-233.

Creswell, J. W. (2002). Research Design:Qualitative,Quantitative And Mixed Method (Vol. 73). USA: SAGE Publications. Https://Doi.Org/10.1111/1467-8292.00187

Febriyanti, F. N., Wulandari, P., Syajarotun, Z., \& Setyana, A. M. (2015). Makalah Model Pembelajaran Numbered Head Together. Yogyakarta: Universitas PGRI Yogyakarta. Https://Doi.Org/10.1080/00949655.2015.1101464.3.

Harmer, J. (2007). The Practice Of English Language Teaching (Fourth). Cambridge: Longman Pearson.

Imro'atul. (2011). Chapter III. State Islamic College (STAIN) Of Tulungagung.

Lisdawati, I., \& Syahrizal, T. (2017). Students' Perception In Applying Lesson Study In Teaching Introduction To Linguistics. Acuity, 2(2), 1-12.

Nurdiana. (2016). Using Numbered Head Together Technique On Students Reading Comprehension. Indonesian Journal Of Integrated English Language Teaching, 2(1), 3748.

Parmawati, A. (2018). The Study Correlation Between Reading Habit And Pronunciation Ability At The Second Grade Students Of Ikip Siliwangi. Eltin Journal, Journal Of English Language Teaching In Indonesia, 6(1), 46-52.

Sinambela, E., Manik, S., \& Pangaribuan, R. E. (2015). Improving Students ' Reading Comprehension Achievement By Using K-W-L Strategy, 4(3), 13-29. Https://Doi.Org/10.5430/Elr.V4n3p13

Sundayana, R. (2016). Statistika Penelitian Pendidikan. Bandung: Alfabeta. 